\title{
Serine/Threonine-Protein Kinase PAK 6
}

National Cancer Institute

\section{Source}

National Cancer Institute. Serine/Threonine-Protein Kinase PAK 6. NCI Thesaurus. Code C30119.

Serine/threonine-protein kinase PAK 6 (681 aa, $75 \mathrm{kDa}$ ) is encoded by the human PAK6 gene. This protein plays a role in regulation of gene transcription. 